\title{
Diet of Wood Pigeon (Columba palumbus) in Forest Areas of Souk Ahras Region (North- Eastern Algeria): Management Implications
}

\author{
Asma Kaouachi ${ }^{1}$, Mohcen Menaa ${ }^{1 *}$, Abderraouf Chouaib Rebbah ${ }^{2}$ and \\ Mohamed Cherif Maazi ${ }^{1}$ \\ ${ }^{1}$ LEAT Laboratory, Department of Biology, Faculty of Nature and Life Sciences, \\ University of Souk Ahras, P.O. 1553, Annaba Road, Souk Ahras, Algeria. \\ ${ }^{2}$ Department of Nature and Life Sciences, Faculty of Sciences, University of Oum \\ El-Bouaghi, P.O. 321, Constantine Road, Oum El Bouaghi, Algeria.
}

\begin{abstract}
A B S T R A C T
The wood pigeon Columba palumbus is a common bird in Algerian forests. In the near past the species populations have increased significantly in Algeria. In order to better comprehend the ecology and vital needs of the wood pigeon and to help with our results in the process of conservation management of wood pigeon, a study of the diet of this pigeon was undertaken from October 2015 to April 2017 within the Souk Ahras region, in North-eastern Algeria. This work was carried out by using a combination of digestivecontents analysis (86 contents) and field observations (during the breeding season). We identified 16 plant species of which four were recorded through on-site observations and 12 species were collected from bird crops. The biomass contained in the alimentary tract showed that fruits dominated the bird diet but the proportion of food items varied among seasons reflecting their seasonal availability in the study area. The pattern of seasonal variation of the diet was similar to most studies on wood pigeon diet. During the autumn and the winter; significant amounts of fruits of mastic tree Pistacia lentiscus and cork oak Quercus suber were consumed. Spring was characterized by the consumption of fruits of olives Olea europea and Aleppo pine Pinus halepensis. The direct field observations permitted to note that the summer diet was dominated by the cereals.
\end{abstract}

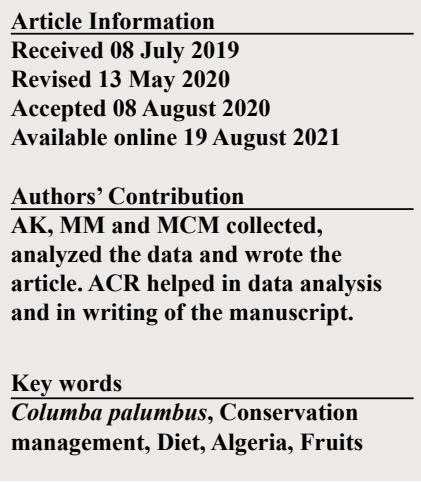

Article Information

Received 08 July 2019

Revised 13 May 2020

Accepted 08 August 2020

Available online 19 August 2021

Authors' Contribution

AK, MM and MCM collected,

analyzed the data and wrote the

article. ACR helped in data analysi

and in writing of the manuscript.

Columba palumbus, Conservatio

management, Diet, Algeria, Fruits

\section{INTRODUCTION}

$\mathrm{D}$ etermining a bird's diet is crucial to many aspects of avian ecology (Sam et al., 2017). The studies carried on the wild bird's diet suggested that the food resources play a major role in determining how much to invest in reproduction, and it ultimately affects the population size (Ruffino et al., 2014). Another way in which food can influence the bird population is via its impact on breeding timing (Newton, 1980; Poulin et al., 1994). Seasonality has a fundamental impact on food availability, which in turn affects abundance, bird distribution, breeding success and the ultimate survival (Mengesha and Bekele, 2008).

Columbidae is one of the most threatened bird families in the world however it has received relatively little conservation attention (Walker, 2007). The wood pigeon belongs to the family Columbidae. It is a Palearctic species that breeds across the European continent, from Russia and

\footnotetext{
Corresponding author: m.menaa@univ-soukahras.dz 0030-9923/2021/0005-1919 \$ 9.00/0

Copyright 2021 Zoological Society of Pakistan
}

Scandinavia to the Atlantic coasts and Mediterranean peninsulas (Saari, 1997; Bea et al., 2003). In North Africa, it is a common resident, passage migrant and widespread breeder (Self, 2014).

The wood pigeon is common in Algerian forests and its populations have increased significantly in previous years (Moali et al., 2003; Merabet et al., 2014; Bendjoudi et al., 2015; Menaa, 2017). In Europe, many studies have investigated the wood pigeon diet. These studies showed that the diet of the wood pigeon is mainly composed of seeds, fruits, and leaves (Colquhoun, 1951; Murton, 1965; Cramp, 1972; Schnock and Seutin, 1973; Folk, 1984; Jimenez et al., 1994; Rouxel and Czajkowski, 2004; Ó hUallachain and Dunne, 2013; Gutiérrez-Galán et al., 2016). The main food species consumed by wood pigeons varied in accordance with their abundance in the study areas; for example, ivy Hedera helix and beech Fagus sylvatica are the main plant species exploited by the wood pigeon in the North-east of Ireland (ÓhUallachain and Dunne, 2013). In southern Spain, the acorns of oaks Quercus spp. and fruit of mastic tree dominated the diet of the wood pigeon (Gutiérrez-Galán et al., 2016). In 
Algeria, Merabet et al. (2014) reported that Oxalis Oxalis pes-caprae and olives are important food items consumed by wood pigeon.

The seasonal variation of the pigeon diet is another story. Many studies highlighted the temporal variation in the consumption of food items by wood pigeon. Seeds and fruits of trees dominate winter and spring diets (Murton, 1965; ÓhUallachain and Dunne, 2013; Merabet et al., 2014). Gutiérrez-Galán et al. (2016) found that fruits of trees also occurred during autumn in a worthwhile proportion. During summer, the wood pigeon feeds almost on cereals, and many studies agree with the great consumption of this food category (Colquhoun, 1951; Jimenez et al., 1994; Gutiérrez-Galán et al., 2016).

In North Africa, only a few studies document the wood pigeon that were limited to annotated checklists and catalogues of bird species in Algeria (Isenmann and Moali, 2000), Morocco (Thévenot et al., 2003) and Tunisia (Isenmann et al., 2005).

Wood pigeon diet in Algeria has been insufficiently examined, and most of the studies are only descriptive (Guezzoul et al., 2004; Merabet et al., 2014). These works showed that the wood pigeon consumes mostly plants with a preference for seeds of Oxalis, barley Hordeum vulgare and wheat Triticum durum in the plain of Mitidja (Merabet et al., 2014; Guezzoul et al., 2004). More research on the diet of this species is sorely needed and especially in our study area, where the wood pigeon is still found in forest areas and it rarely spreads over agricultural and urban areas. Besides wood pigeon is a game species that needs better management interventions. In order to redress this lack of information, we have studied the diet composition of this species and its seasonal variation in three forests within the Souk Ahras region, in North-eastern Algeria.

The primary aim is to understand the ecology of the wood pigeon in the region of Souk Ahras and increase the knowledge of the diet of this species. The research objectives were to evaluate the ecological requirements of this game bird and to develop conservation management strategies for this species in forest areas.

\section{MATERIALS AND METHODS}

Study area

The study was carried out from October 2015 to March 2017 at three forests within the region of Souk Ahras, in North-eastern Algeria (Fig. 1, Table I), where wood pigeon are reported to be hunted.

\section{Data collection}

In total, 86 individual wood pigeon (54 males and 32 females) were collected and examined between October 2015 to March 2017. The birds were hunted by local hunters. They were dissected for crop content analysis. All the crops were removed and emptied into Petri dishes and the contents were weighed on a digital scale with an accuracy of $0.0001 \mathrm{~g}$. The food items were examined and separated under a binocular microscope LEICA with a magnification of $10 \times 40 \mathrm{~mm}$. The sorted items were conserved in ethanol at $70^{\circ}$.

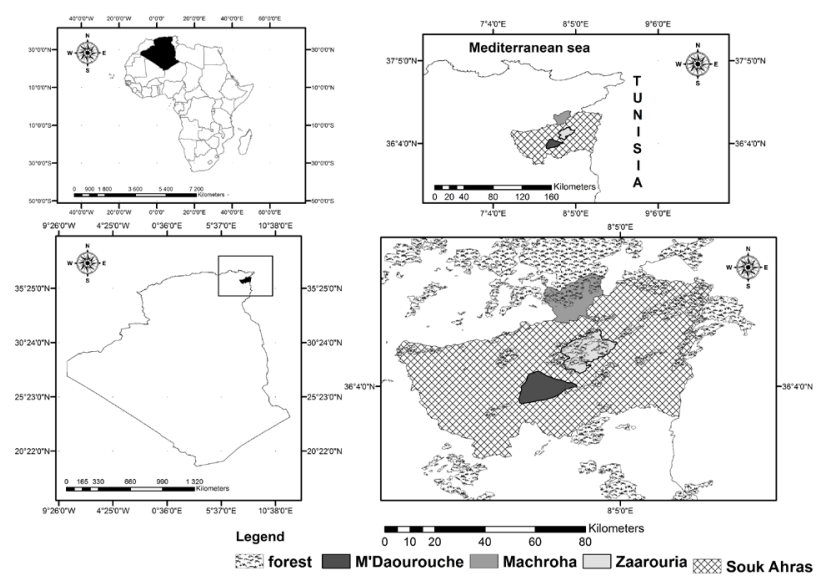

Fig. 1. Geographic location of the study area.

Table I. Summary of description for the sampling sites in the region of Souk Ahras.

\begin{tabular}{llll}
\hline & \multicolumn{2}{c}{ Sites } & \\
\cline { 2 - 4 } & Natural forest of Ouled Bechih & Natural forest of Zaarouria & Reforestation of Boussessou \\
\hline Habitat type & Cork oak stands and zeen oak stands & Aleppo pine stands & Aleppo pine stands \\
Municipality & Mechroha & Zaarouria & M'Daourouch \\
Coordinates & $36^{\circ} 21^{\prime} 26^{\prime \prime} \mathrm{N}, 7^{\circ} 50^{\prime} 08^{\prime \prime} \mathrm{E}$ & $36^{\circ} 13^{\prime} 38^{\prime \prime} \mathrm{N}, 7^{\circ} 57^{\prime} 28^{\prime \prime} \mathrm{E}$ & $36^{\circ} 04^{\prime} 29^{\prime \prime} \mathrm{N}, 7^{\circ} 49^{\prime} 11^{\prime \prime} \mathrm{E}$ \\
Altitude & $790-1050$ & $680-717$ & $943-1067$ \\
Annual pricipitation $(\mathrm{mm})$ & 762 & 687 & 587 \\
Monthly temperature $\left({ }^{\circ} \mathrm{C}\right)$ & 14.0 & 14.5 & 13.8 \\
Climate & Sub-humid & Sub-humid & Semi-arid \\
\hline
\end{tabular}


Food items were classed into three categories: cereals: (seeds of barley), fruits: (acorns and other fruits consumed by wood pigeon), grass clover (leaves of clover Trifolium sp.).

Outside the legal hunting season, we observed the feeding sites and recorded the species on which the wood pigeons were feeding. The observations on the feeding sites were not detailed; our results are based on general simple observations and the information given by the local residents.

The body weight of entire birds was measured with an electronic balance (to the nearest $1.0 \mathrm{~g}$ ), distinguishing between sexes and season.

Seasonal changes in diet were evaluated by comparing wood pigeons haunted in autumn (October to November), winter (December to February) and high spring (March to April). The determination of sex was by examination of gonads following dissection.

\section{Statistical analyses}

Data on richness and body weight were analyzed for both the overall total and for each season and sex. To analyze differences in diet composition between seasons as well as between sexes, a Permutational Multivariate Analysis of Variance procedure (PERMANOVA) was used with the ADONIS function (Anderson, 2001) included in the "vegan" package for R 3.1.0 (R Core Team, 2016) software (Oksanen et al., 2007). This procedure acts as a matrix based non-parametric analysis of variance. PERMANOVA analyzes and segment sums of squares using semi-metric and metric distance matrices using permutation methods (Anderson, 2005).

To analyze seasonal differences in the relative consumption of food categories, overall crop weight and dietary richness, a non-parametric Kruskal-Wallis one-way analysis of variance (ANOVA) test, using the R function, kruskal.test, was used (Kruskal and Wallis, 1952). The test used a single factor with three levels: One for each of the seasons (autumn, winter and high spring). Then Student ' $\mathrm{t}$ ' test analysis was used (Zimmerman and Zumbo, 1993) to test for differences in relative consumption of food categories, overall crop weight and dietary richness between sexes.

\section{RESULTS}

Overall, we analyzed 86 crops of wood pigeon; all were hunted in Souk Ahras region between October 2015 and March 2017.

During the study period, 16 species of plant foods were identified. Thirty species were found in the crops and five of them were observed during the fieldwork.
Considering all the consumed items in the analyzed crops, the wood pigeon was exclusively herbivorous; no animal species were recorded during this study. Table II summarizes all the plant species consumed by pigeons or recorded during the fieldwork.

The diet composition was examined to see if there was a difference between seasons and sexes. Permanova analysis revealed a clear difference between seasons (Adonis: $\mathrm{F}_{2.83}=7.9391, p<0.001$ ), but not between sexes (Adonis: $\mathrm{F}_{2.83}^{2.83}=1.0719, p>0.05$ ).

The total weight of consumed items by all studied wood pigeons (86 individuals) was $2276.1 \mathrm{~g}$ and the average weight of crop contents was $28.45 \pm 10.86 \mathrm{~g}$.
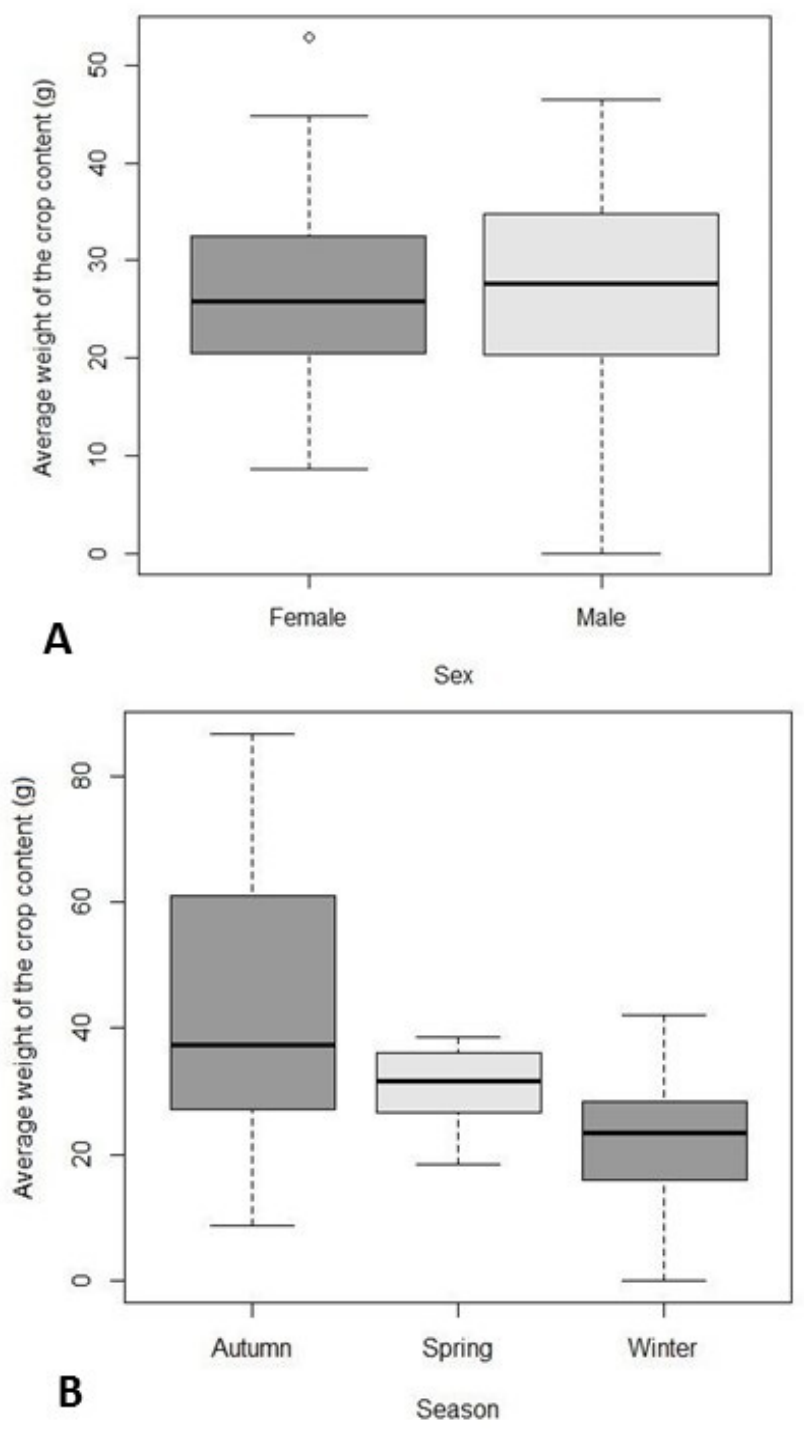

Fig. 2. Variation of the average weight of food content in the crops between sexes (A) and seasons (B). 


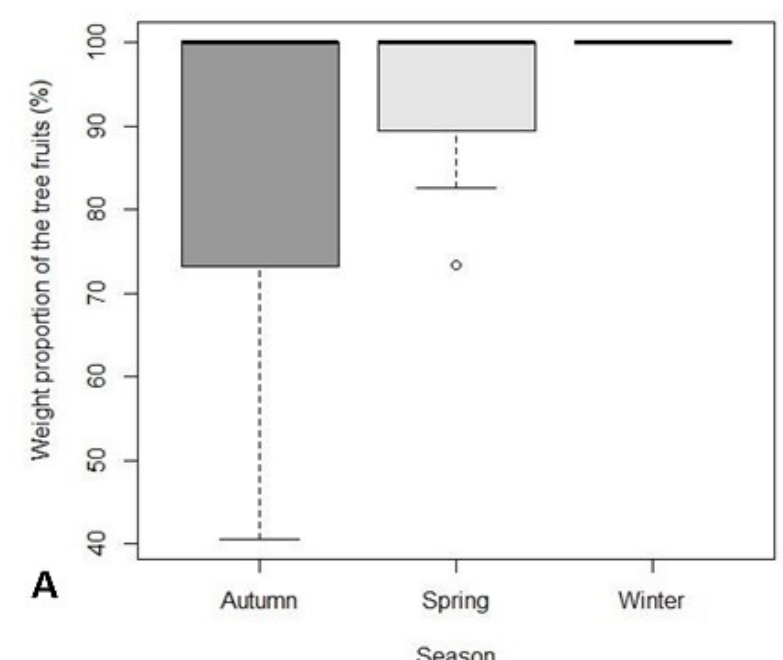

In comparison between males and females, the average weight $( \pm \mathrm{sd})$ of the crop content in males $(29.42 \pm 10.9 \mathrm{~g})$ was almost similar to that of females $(26.89 \pm 10.79 \mathrm{~g})$. Statistically, there was no significant difference between males and females ( $t$ test: $t_{1.84}=-0.7622, p>0.05$ ) (Fig. $2 \mathrm{~A})$. The variability of the average weight through seasons was significant (Kruskal-Wallis test: $\chi_{2.83}^{2}=14.8451, p<$ 0.001) (Fig. 2B).

Table II. Food items consumed by the wood pigeon Columba palumbus in the region of Souk Ahras during the study period 2015-2017.

\begin{tabular}{lll}
\hline $\begin{array}{l}\text { S. } \\
\text { No. }\end{array}$ & $\begin{array}{l}\text { Food items recorded by } \\
\text { examining crop contents }\end{array}$ & $\begin{array}{l}\text { Food items recorded by } \\
\text { observing pigeons feeding }\end{array}$ \\
\hline 01 & Mastic & \\
02 & Mount Atlas mastic tree & \\
03 & Cork oak & \\
04 & Zeen oak & \\
05 & Evergreen oak & \\
06 & Aleppo pine & \\
07 & Common ivy & Mediterranean hackberry \\
08 & Mediterranean hackberry & Barley \\
09 & Barley & Wheat \\
10 & & Oat \\
11 & & \\
12 & Mock privet & Ash \\
13 & & \\
14 & Olives & \\
15 & Sensitive plant & \\
16 & Clover & \\
\hline
\end{tabular}

1, Food items recorded by examining crop contents; 2, Food items recorded by observing feeding pigeons.

The different food categories consumed by the wood pigeon varied through seasons (Fig. 3). The tree fruits were the best represented food category in the wood pigeon diet. This category accounted $(93.25 \pm 17.43 \%)$ for the total weight of consumed items. It was present in the diet of $98.83 \%$ of the analyzed crops of birds. The main constituents of this food category account for fruits of mastic tree $(34.52 \%)$ and acorns of cork oak (30.58\%). There was a significant seasonal difference in the weight proportion of tree fruits in the diet (Kruskal-Wallis: $\chi_{2.83}^{2}=$ 15.55, $p<0.01$ ) (Fig. 3A).

The cereals made up $6.00 \pm 17.29 \%$ of the bird diet

Fig. 3. Variation of the average weight of tree fruits (A), clover (B) and cereals (C) consumed by the wood pigeon among seasons. and occurred in $12.79 \%$ of crops. Cereals were exclusively represented by barley. In addition, wood pigeon were observed feeding on wheat and oats Avena sativa during 
the fieldwork. The items in this category were consumed only in summer and autumn. There was a significant seasonal difference in the weight proportion of consumed cereal grains (Kruskal-Wallis test: $\chi_{2.86}^{2}=18.9492, p<0.01$ ) (Fig. 3B).

The clover showed a highly significant difference in term of relative proportion between seasons (KruskalWallis test: $\chi_{86.2}^{2}=25.8857, p<0.01$ ) (Fig. 3C). This food category represented a minor proportion of the diet of wood pigeon $(0.76 \pm 3.74 \%)$. In autumn, the wood pigeon diet was dominated by tree fruits constituting $(84.83$ $\pm 25.03 \%$ ) and occurred in $97.05 \%$ of crops. Considering the weight proportion, the most important items in this category were mastic tree fruits $(48.59 \%)$, followed by Mediterranean hackberry Celtis australis (19.76\%), and zeen oak Quercus canariensis (11.26\%). The autumn diet included other species recorded in small amounts (Mount Atlas mastic tree Pistacia atlantica, Mock privet Phyllerea angustifolia, Aleppo pine and zeen oak).

Cereals also constituted a large proportion of the autumn diet $(17 \pm 25.03 \%)$ and were found in $32.35 \%$ of the analyzed samples.

The consumption of tree fruits was the most recorded in winter, the diet was exclusively made by tree fruits representing $100 \%$ of crop contents mass and being present in all the analyzed crops (100\%). Two species were found in major proportions viz., cork oak $(46.32 \%)$ and mastic tree $(33.99 \%)$. Mock privet, zeen oak and Sensitive plant Mimosa pudica together represented less than $20 \%$ of the consumed materials.

In spring also, the diet analysis revealed that the tree fruits which represented $(94.57 \pm 8.97 \%)$ of the crop contents, occurred in all the examined crops. The most eaten fruits were cork oak (36.53\%), Aleppo pine (30.55\%) and olives (30.11\%). Berries of Ivy accounted for $2.78 \%$ of the spring diet. The clover was found with a low weight proportion $(5.43 \pm 8.97 \%)$ but was reported in $33.33 \%$ of studied crops.

\section{DISCUSSION}

Few quantitative data exist on the diet of the wood pigeon in Algeria and North Africa. This study provides a detailed description of the species diet in a Mediterranean forest in North-eastern Algeria.

In our study area, the number of plant species consumed by wood pigeon was smaller than reported in similar studies in Algeria (Guezzoul et al., 2004; Merabet et al., 2014) and in Europe (Murton et al., 1963; Schnock and Seutin, 1973; ÓhUallachain and Dunne, 2013; Gutiérrez-Galán et al., 2016). This lower food diversity may be due to the higher availability of a few preferred food items over long periods of the year (Whelan and Brown, 2005; Molokwu et al., 2011; Gutiérrez-Galán et al., 2016). It has already been seen in other studies in the case of acorns (Purroy et al., 1984; Díaz and Martín, 1998) and olives (Merabet et al., 2014), a fact also reported in our results. Wood pigeon extensively foraged on the most abundant and available species i.e. acorns of cork oak and fruits of mastic tree.

Animal materials were absent from the wood pigeon diet in our study area. This result is consistent with the findings of other researchers (Folk, 1984; Purroy et al., 1984; Jiménez et al., 1994; Gutiérrez-Galán et al., 2016). In this study, the analyzed birds were not hunted during the breeding season when many herbivorous birds take in as many insects as possible (Ehrlich et al., 1988). Columbiformes consume additional calcium-rich material during their egg-laying period (Murton et al., 1964; Ó hUallachain and Dunne, 2013).

The basis of the wood pigeon diet is made up of tree fruits. This result is similar to those of Murton (1965), Purroy et al. (1984), ÓhUallachain and Dunne (2013) and Gutiérrez-Galán et al. (2016). Among the most prominent consumed items in this food category, fruits of mastic tree and acorns of cork oak were the most taken species.

Traditionally, the diet varies throughout the day, the year, and between years, sites, sexes, and even between individuals (Sutherland et al., 2004). According to our results, variation in diet composition of the wood pigeon has been significant through the seasons. This variation can be related to the fact that the consumption of food items depends on their availability in the study area (Fuentes, 1994; O’Donnell and Dilks, 1994; Gutiérrez-Galán et al., 2016).

During the autumn, wood pigeon fed predominantly on mastic tree fruits. This important use of mastic tree seems to be related to the peak in fruit abundance, which reaches high levels between October and January (Herrera, 1984). It is also coincident with the fruiting season of mastic tree. In addition, it could be related to the digestive physiology of birds and the pulp composition of fruits of the Pistacia genus (Fuentes, 1994).

Contrary to our finding, in the plains of Mitidja (Algeria), mastic tree fruits represented a minor item in the wood pigeon diet. However, olives were more preferred (Merabet et al., 2014). This difference may be due to the fact that the fruits of the mastic tree have less fat value $(15.9 \%)$ than olives (41.9\%) (Jordan and Herrera, 1981). It may also be linked to difference in the habitat structure between Souk Ahras forests largely dominated by fruit trees and the Mitidja Plain which is mainly an agricultural region.

The wood pigeon completed its autumn diet with other items including acorns of cork oak. Significant 
consumption of acorns during autumn has been highlighted by many others authors (Purroy et al., 1984; Díaz and Martín, 1998; Verdu et al., 2010; Bendjoudi et al., 2015; Gutiérrez-Galán et al., 2016).

During the winter, tree fruits dominated the diet; mastic tree and cork oak were the most exploited by wood pigeon. Both species are widely available in the study area. It has been proposed that frugivory can be advantageous because of the low energetic cost involved in fruit-feeding (O’Donnell and Dilks, 1994). Many authors reported a preferred consumption of acorns in winter (Verdu et al., 2010; Bendjoudi et al., 2015; Gutiérrez-Galán et al., 2016). The acorns are an important energy source as they contain high levels of fatty acids (Heitmeyer and Fredrickson, 1981; Reinecke, 2017). Additionally, efficient consumption of oak acorns may decrease the time required to fill their stomachs (Reinecke, 2017).

The wood pigeon continued feeding on acorns until March. Other studies on wood pigeon diet reported this consumption until high spring (March) (Leiva and Fernández-Alés, 2003; González-Rodríguez and Villar, 2012; Gutiérrez-Galán et al., 2016).

In spring, the food spectrum of wood pigeon became more diverse as other food items became available, related to the growth of ground vegetation (Petty, 1999). The other items included Aleppo pine, olives and clover. It is important to note that the occurrence of Aleppo pine was due to the fact that the wood pigeons were hunted in pine forests.

Although clover constituted a minor percentage of the spring diet, it occurred in $30 \%$ of crops. It has been suggested that pigeons feed on foliage to complement the scarcity of fruits (O'Donnell and Dilks, 1994; Oliveira et al., 2002; Ando et al., 2017). The green foods are an important source of many essential elements for wood pigeon (Cramp, 1972).

On the other hand, olives were represented in large proportions during high spring. As in other studies (Cramp, 1972; Huysentruyt et al., 2013; Perea and Gutiérrez-Galán, 2016; Gutiérrez-Galán et al., 2016), the consumption of olives by wood pigeon reaches considerable values from March on wards when pigeons start to reproduce.

Another study in Algeria (Merabet et al., 2014) found that oxalis substituted acorns and olives as the most prominent food item in the spring diet of wood pigeon. The absence of this species in the crops in our study can be explained by the fact that oxalis is not widely found in the study area.

Our observations on the field work during summer showed that the wood pigeon food depended on cereals.
Flocks of wood pigeon were observed in cultivated fields on the edge of forests, feeding mostly on wheat, barley and oats. Similarly, consumption of cereals has been highlighted by several authors (Purroy et al., 1984; Gutiérrez-Galán et al., 2016). Other studies found that cereals dominated the autumn/ late summer diet. This difference could stem from the changes in agricultural practices from winter-sown to spring-sown crops (ÓhUallachain and Dunne, 2013). Some birds were also seen ingesting Mediterranean hackberry during late summer. Merabet et al. (2014) reported a similar result in Algeria.

The pattern of seasonal variation of the diet was similar to most studies on wood pigeon diet (ÓhUallachain and Dunne, 2013; Merabet et al., 2014; Gutiérrez-Galán et al., 2016).

The consumption level of of some food items does not necessarily reflect strong selection or preference but likely an opportunistic diet (Marrero et al., 2004). The Absolute preferences can only be inferred outside of the context of fruit abundance (Parrish, 1997).

\section{CONCLUSION}

We identified the food spectrum of the wood pigeon in Souk Ahras region. Overall, the diet of the wood pigeon fitted into the known pattern. The temporal variation in the diet was significant. As in other studies, our preliminary data showed that the tree fruits dominated the diet during all the seasons excepting the summer in which cereals were the most consumed. Our data collected from three forest areas suggest that the wood pigeon is a generalist/ opportunistic feeder, feeding on various food items and switching to alternative species when preferred food was not available. Furthermore, we suggest that the relationship between the composition of the diet and the availability of foods still requires clarification. Finally, this study has important implications for the conservation and the management of the wood pigeon in the forests of Souk Ahras and possibly other similar woodland areas.

\section{ACKNOWLEDGEMENTS}

We would like to acknowledge the Directorate General for Scientific Research and Technological Development (DGRSDT) for supporting this study. We would like to thank local hunters for their contribution in field work.

\section{Statement of conflict of interest}

The Authors have declared no conflict of interest. 


\section{REFERENCES}

Anderson, M.J., 2001. A new method for nonparametric multivariate analysis of variance. Aust. Ecol., 26: 32-46. https://doi.org/10.1046/j.14429993.2001.01070.x

Anderson, M.J., 2005. Permutational multivariate analysis of variance. Department of Statistics, University of Auckland, Auckland.

Ando, H., Sasaki, T., Horikoshi, K., Suzuki, H., Chiba, H., Yamasaki, M. and Isagi, Y., 2017. Wideranging movement and foraging strategy of the critically endangered red-headed wood pigeon (Columba janthina nitens): Findings from a remote uninhabited island. Pac. Sci., 71: 161-171. https:// doi.org/10.2984/71.2.5

Bea, A., Beitia, R. and Fernández, J.M., 2003. The census and distribution of wintering woodpigeons Columba palumbus in the Iberian Peninsula. Ornis Hung., 12: 157-167.

Bendjoudi, D., Voisin, J.F., Doumandji, S., Merabet, A., Benyounes, N. and Chenchouni, H., 2015. Rapid increase in numbers and change of landuse in two expanding Columbidae species (Columba palumbus and Streptopelia decaocto) in Algeria. Avian Res., 6: 18. https://doi.org/10.1186/ s40657-015-0027-9

Colquhoun, M.K., 1951. The woodpigeon in Britain. HMSO, London.

Cramp, S., 1972. The breeding of urban woodpigeons. IBIS, 114: 163-171. https://doi.org/10.1111/j.1474919X.1972.tb02601.x

Díaz, M. and Martin, P., 1998. Habitat selectivity in wintering wood pigeons (Columba palumbus) in holm oak dehesas of central Spain. Gibier Faune Sauvage, 15: 167-181.

Ehrlich, P., Dobkin, D.S. and Wheye, D., 1988. Birder's handbook. Simon and Schuster.

Folk, C., 1984. The summer diet of the woodpigeon. Folia Zool., 33: 41-47.

Fuentes, M., 1994. Diets of fruit-eating birds: What are the causes of interspecific differences. Oecologia, 97: 140-142. https://doi.org/10.1007/BF00317917

González-Rodríguez, V. and Villar, R., 2012. Postdispersal seed removal in four Mediterranean oaks: Species and microhabitat selection differ depending on large herbivore activity. Ecol. Res., 27: 587-594. https://doi.org/10.1007/s11284-012-0927-7

Guezzoul, O., Doumandji, S., Souttou, K., Baziz, B. and Brahmi, K., 2004. Première mention sur le comportement trophique des adultes du Pigeon ramier Columba palumbus Linné, 1758 et du pigeon biset Columba livia bonnaterre, 1790 dans un milieu sub-urbain près d'el Harrach. Ornith. Algir., 4: 11-16.

Gutiérrez-Galán, A., González, C.A. and Mercado, J.M. De., 2016. Woodpigeon Columba palumbus diet composition in Mediterranean Southern Spain. Ardeola, 64: 17-30. https://doi.org/10.13157/ arla.64.1.2017.ra2

Heitmeyer, M.E. and Fredrickson, L.H., 1981. Do wetland conditions in the Mississippi Delta hardwoods influence mallard recruitment? Trans. N. Am. Wildl. Nat. Resour. Conf., 46: 44-57.

Herrera, C.M., 1984. A study of avian frugivores, birddispersed plants, and their interaction in Mediterranean scrublands. Ecol. Monogr., 54: 1-23. https://doi.org/10.2307/1942454

Huysentruyt, F., Baert, K. and Casaer, J., 2013. Onset of common woodpigeon Columba palumbus breeding season in Flanders as based on gonadal development. Ardea, 101: 45-49. https://doi. org/10.5253/078.101.0106

Isenmann, P. and Moali, A., 2000. Oiseaux d'Algérie. Société d'Études Ornithologiques de France S.E.D.F., Paris.

Isenmann, P., Gaultier, T., El Hili, A., Azafzaf, H., Dlensi, H. and Smart, M., 2005. Oiseaux de Tunisiel Birds of Tunisia. SEOF, Paris.

Jiménez, R., Hodar, J.A. and Camacho, I., 1994. Diet of the woodpigeon (Columba palumbus) in the south of Spain during late summer. Folia Zool., 43: 163170.

Jordan, C.F. and Herrera, R., 1981. Tropical rain forests: Are nutrients really critical? Am. Natural., 117: 167-180. https://doi.org/10.1086/283696

Kruskal, W.H. and Wallis, W.A., 1952. Use of ranks in one-criterion variance analysis. J. Am. Stat. Assoc., 47: 583-621. https://doi.org/10.1080/01621 459.1952.10483441

Leiva, M.J. and Fernández-Alés, R., 2003. Postdispersive losses of acorns from Mediterranean savannah-like forests and shrublands. For. Ecol. Manage., 176: 265-271. https://doi.org/10.1016/ S0378-1127(02)00294-3

Marrero, P., Oliveira, P. and Nogales, M., 2004. Diet of the endemic Madeira Laurel Pigeon Columba trocaz in agricultural and forest areas: Implications for conservation. Bird Conserv. Int., 14: 165-172. https://doi.org/10.1017/S0959270904000218

Menaa, M., 2017. Structure et dynamique de l'avifaune nicheuse de la forêt domaniale de Boumezrane (Ain Zana, Souk-Ahras). Thèse de Doctorat, Université d’Oum El Bouaghi, Oum El Bouaghi, pp. 133. 
Mengesha, G. and Bekele, A., 2008. Diversity and relative abundance of birds of Alatish National Park. Int. J. Ecol. environ. Sci., 34: 215-222.

Merabet, A., Chebouti-Meziou, N., Chebouti, Y., Bissaad, F.Z. and Doumandji, S., 2014. The diet of the woodpigeon Columba palumbus the edge of the plain of Mitidja (North Algeria). Rev. Écol. (Terre Vie), 69: 3-4.

Moali, A., Moali-Grine, N., Fellous, A. and Isenmann, P., 2003. Expansion spatiale de la Tourterelle Turque Streptopelia decaocto et présence dans les parcs urbains du Pigeon Ramier Columba palumbus en Algérie. Alauda, 71: 371-374.

Molokwu, M., N., Nilsson, J. and Olsson, O., 2011. Diet selection in birds: trade-off between energetic content and digestibility of seeds. Behav. Ecol., 22: 639-647. https://doi.org/10.1093/beheco/arr025

Murton, R.K., 1965. The wood pigeon. Collins, London, UK.

Murton, R.K., Isaacson, A.J. and Westwod, N.J., 1963. The food and growth of nestling wood-pigeons in relation to the breeding seasosn. Proc. zool. Soc. Lond., 133: 747-782.

Murton, R.K., Westwood, N.J. and Isaacson, A.J., 1964. The feeding habits of the woodpigeon Columba palumbus, Stock Dove C. oenas and Turtle Dove Streptopelia turtur. IBIS, 106: 174-188. https://doi. org/10.1111/j.1474-919X.1964.tb03694.x

Newton, I., 1980. The role of food in limiting bird numbers. Ardea, 68: 11-30. https://doi.org/10.5253/ arde.v68.p11

Ó hUallachain, D. and Dunne, J., 2013. Seasonal variation in the diet and food preference of the Woodpigeon Columba palumbus in Ireland. Bird Study, 60: 417-422. https://doi.org/10.1080/00063 657.2013.798259

O’Donnell, C.F. and Dilks, P.J., 1994. Foods and foraging of forest birds in temperate rainforest, South Westland, New Zealand. N. Z. J. Ecol., 18: 87-107.

Oksanen, J., Kindt, R., Legendre, P., O’Hara, B., Stevens, M.H.H., Oksanen, M.J. and Suggests, M.A.S.S., 2007. The vegan package. Commun. Ecol. Package, 10: 631-637. https://doi. org/10.1111/j.1654-1103.2003.tb02228.x

Oksanen, J., 2013. Vegan ecological diversity-vegan. 2.0-7 in R version 2.15.2 (2013-03-19).

Oliveira, P., Marrero, P. and Nogales, M., 2002. Diet of the endemic Madeira Laurel Pigeon and fruit resource availability: A study using microhistological analyses. Condor, 104: 811-822. https://doi.org/10.1093/condor/104.4.811
Parrish, J.D., 1997. Patterns of frugivory and energetic condition in Nearctic land birds during autumn migration. Condor, 99: 681-697. https://doi. org/10.2307/1370480

Perea, R. and Gutiérrez-Galán, A., 2016. Introducing cultivated trees into the wild: Wood pigeons as dispersers of domestic olive seeds. Acta Oecol., 71: 73-79. https://doi.org/10.1016/j.actao.2015.09.005

Petty, S.J., 1999. Diet of tawny owls (Strix aluco) in relation to field vole (Microtus agrestis) abundance in a conifer forest in northern England. J. Zool., 248: 451-465.https://doi.org/10.1111/j.1469-7998.1999. tb01045.x

Poulin, B., Lefebvre, G. and McNeil, R., 1994. Diets of land birds from northeastern Venezuela. Condor, 96: 354-367. https://doi.org/10.2307/1369320

Purroy, F.J., Tomiałojć, L. and Rodero, M., 1984. The Ecology of woodpigeons Columba Palumbus Wintering on the Iberian Penisula. Państwowe Wydawnictwo Naukowe.

R Development Core Team, 2016. R: A language and environment for statistical computing $R$ Foundation for Statistical Computing. Vienna, Austria. http:// www.R-project.org

Reinecke, L., Aufenanger, S., Beutel, M.E., Dreier, M., Quiring, O., Stark, B. and Müller, K.W., 2017. Digital stress over the life span: The effects of communication load and internet multitasking on perceived stress and psychological health impairments in a German probability sample. Media Psychol., 20: 90-115. https://doi.org/10.108 0/15213269.2015.1121832

Rouxel, R. and Czajkowski, A., 2004. Le pigeon ramier Columba palumbus L. Ed. OMPO, Société de Presse Adour-Pyrénées, Lourdes, France.

Ruffino, L., Salo, P., Koivisto, E., Banks, P.B. and Korpimaki, E., 2014. Reproductive responses of birds to experimental food supplementation: A meta-analysis. Front. Zool., 11: 80. https://doi. org/10.1186/s12983-014-0080-y

Saari, L., 1997. Woodpigeon. In: Bea, A., Beitia, R. and Fernández, J.M., 2003. The census and distribution of wintering woodpigeons Columba palumbus in the Iberian Peninsula. Ornis Hung., pp. 157-167.

Sam, K., Koane, B., Jeppy, S., Sykorova, J., and Novotny, V., 2017. Diet of land birds along an elevational gradient in Papua New Guinea. Nature Publishing Group. https://doi.org/10.1038/srep44018

Schnock, G. and Seutin, E., 1973. Contribution à l'étude écologique du Pigeon ramier (Columba palumbus) en Belgique. Aves, 10: 182-192.

Self, A., 2014. The birds of London (Helm County 
Avifauna).

Sutherland, W.J., Newton, I. and Green, R.E., 2004. Bird ecology and conservation: A handbook of techniques. Oxford University Press. https://doi. org/10.1093/acprof:oso/9780198520863.001.0001

Thévenot, M., Vernon, R. and Bergier, P., 2003. The birds of Morocco: An annotated checklist. British Ornithologists' Union, Tring, UK. https://doi. org $/ 10.2989 / 00306520409485437$

Verdu, J. R., Casas, J. L., Lobo, J. M. and Numa, C., 2010. Dung beetles eat acorns to increase their ovarian development and thermal tolerance. PLoS One, 5 https://doi.org/10.1371/journal.pone.0010114
Walker, J.S., 2007. Geographical patterns of threat among pigeons and doves (Columbidae). Oryx, 41: 289299. https://doi.org/10.1017/S0030605307001016

Whelan, C.J. and Brown, J.S., 2005. Optimal foraging and gut constraints: Reconciling two schools of thought. Oikos, 110:481-496. https://doi. org/10.1111/j.0030-1299.2005.13387.x

Zimmerman, D.W. and Zumbo, B.N., 1993. Rank transformations and the power of the Student $t$-test and Welch $t^{\prime}$-test for non-normal populations. Can. J. exp. Psychol., 47: 523-539. https://doi. org/10.1037/h0078850 